\title{
Quality Standard of Safoof razyanaj: A Unani Polyherbal Powder Formulation
}

\author{
Mohd Ikram, Hamiduddin*, Gazi Jahangeer Rather, Mohd Zaigham \\ Department of IImul Saidla (Unani Pharmacy), National Institute of Unani Medicine (NIUM), Bangalore, Karnataka, INDIA.
}

\begin{abstract}
Objectives: Safoof razyanaj (SR) a Unani polyherbal powder formulation used in dyspepsia, distension of stomach and anorexia. Standardization data of SR. by using scientific analytical procedures was established. Methods: Cleaned and dried powder of plant drug was prepared as per the method described in Unani Pharmacopeia of India (UPI). SR formulation was evaluated using physicochemical tests: powder characterization, extractive value, alcohol and water-soluble matter, Ash value, LOD at $105^{\circ} \mathrm{C}$, pH and HPTLC fingerprinting. Results: SR color was light brown, aromatic and sweetish in taste. Physicochemical parameters expressed as mean values of the three readings showed loss of weight on drying, total ash, acid insoluble ash and watersoluble ash as $4.62 \pm 0.10,4.95 \pm 0.05,1.83 \pm 0.03$ and $2.10 \pm 0.03$ respectively. The Bulk density, tapped density, angle of repose, Hauser's ratio and compressibility index were $0.46 \pm 0.01,0.56 \pm 0.00,35.62 \pm 0.45,1.23 \pm$ 0.00 and $19.24 \pm 0.59$ respectively, $\mathrm{pH}$ of $1 \%$ and $10 \%$ solution were 4.78 \pm 0.03 and $5.08 \pm 0.02$ respectively. Extractive values in petroleum ether, benzene and ethyl alcohol by successive extraction method were $11.24 \pm$
\end{abstract}

$0.14,2.08 \pm 0.04$ and $6.73 \pm 0.10$ respectively. Extractive values in petroleum ether, benzene, ethyl alcohol and water by non-successive extraction method were $11.24 \pm 0.14,15.44 \pm 0.24,32.20 \pm 0.13$ and $34.28 \pm 0.18$ respectively. Qualitative analysis showed presence of alkaloid, tannin, terpenoid, protein, carbohydrate, phenol, glycoside, flavonoid and saponin. HPTLC fingerprinting data of SR in methanolic extract and mobile phase toluene: ethyl acetate: formic acid (5:4:1) was set in. Conclusion: Standardization data of SR was obtained.

Key words: Safoof razyanaj, Standardization, Unani, Powder, Formulation.

Correspondence

Dr. Hamiduddin,

Assistant Professor, Department of IImul Saidla (Unani Pharmacy), National Institute of Unani Medicine (NIUM), Kottigepalya, Magadi Main Road Bangalore-560091, Karnataka, INDIA.

Email: drhamid2003@rediffmail.com

DOI: 10.5530/jyp.2019.11.74

\section{INTRODUCTION}

The use of herbs and their formulations to treat diseases has stood since from long time. The chemical constituents present in herbal medicine are a part of the physiological functions of living flora and hence they are believed to have better acceptance within the human body. That is why herbs and their products are now the centre of discussion for researchers and applications of it in treating the diseases. In old times, Hakims used to treat patients on individual basis and prepare drug according to the need or requirements of the patient. Today herbal medicines are manufactured on a large scale basis in mechanical units, where manufacturers come across many problems such as non-availability of good quality raw materials, non-availability of SOP (Standard Operational Procedure) for manufacturing procedure, proper methodology for standardization and Standardization data etc. ${ }^{1}$ Safoof razyanaj (SR) is a polyherbal formulation used in the Unani System of Medicine for treatment of Su-e-Hazm (dyspepsia), Nafakh-e-Shikam (distension of stomach), Riyah-e-Basoora and Zof-e-Ishteha (anorexia) since ages and the formulation is mentioned in National Formulary of Unani Medicine. This formulation contains Badiyan Biryan (roasted) (Foeniculum vulgare Mill.), Kishneez Khushk Biryan (Coriandrum sativum Linn.), Qand Safaid (Sugar crystal). ${ }^{2}$ This formulation is not evaluated for its physicochemical standardization and microbiological characterization since yet. Thus, keeping this in mind, the present study was carried out to fix the quality control standards of Safoof razyanaj (SR) with scientific analytical techniques.

\section{METHODOLOGY}

Procurement of raw drugs: Ingredients of Safoof razyanaj (SR) was procured from the herbal / raw drug dealer at Bengaluru, Karnataka, India during the month of March. The identification of these drugs was done by the experts of National Institute of Unani Medicine, Kottigepalya, Bengaluru.

Preparation of Formulation: All the drugs mentioned below in different proportions were dried in shade and powdered and passed through sieve no. 80. The formulation was prepared as the method described in National Formulary of Unani Medicines. ${ }^{2}$ (Figure 1), Ingredient and proportion of the formulation is mentioned in Table 1.

\begin{tabular}{ccc}
\multicolumn{2}{c}{ Table 1: Ingredients of the formulation with its proportion. } \\
\hline Drug name & Botanical name & Proportion \\
\hline Badiyan (Biryan /roasted) & Foeniculum vulgare Mill. & $50 \%$ \\
Kishneez Khushk (Biryan /roasted) & Coriandrum sativum Linn. & $50 \%$ \\
Qand Safaid (Sugar crystal) & Sugar crystal & Q.S. \\
\hline
\end{tabular}

Note: Sugar was taken equal to one part of drug in the formulation according to taste.

Physico-chemical evaluation: Prepared Safoof razyanaj (SR) was evaluated for various parameters like organoleptic characters e.g. color, odor and taste. ${ }^{3}$

Powder Characterization: The angle of repose indicates the flowability of the substance. The funnel was adjusted such that the stem of the funnel lies $2 \mathrm{~cm}$ above the horizontal surface. The drug powder was allowed to flow from the funnel under the gravitational force till the apex of the pile just touched the stem of the funnel, so the height of the pile was taken as $2 \mathrm{~cm}$. Drawing boundary along the circumference of the pile and taking the average of six diameters determined the diameter of the

This is an open access article distributed under the terms of the Creative Commons Attribution-NonCommercial-ShareAlike 4.0 License, which allows others to remix, tweak, and build upon the work non-commercially, as long as the author is credited and the new creations are licensed under the identical terms. 


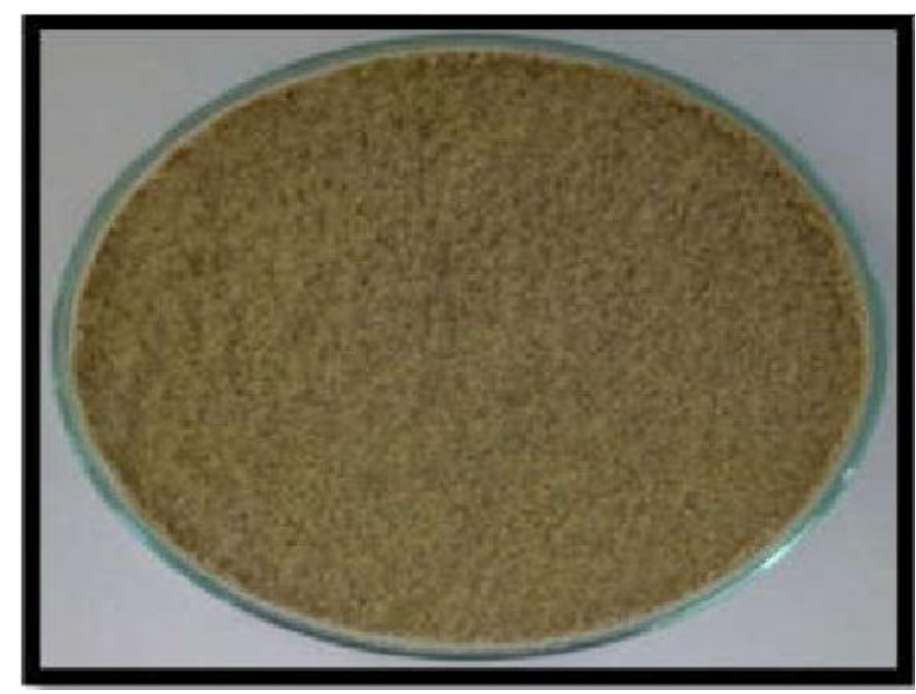

Figure 1: Safoof razyanaj (SR).

pile. These values of height and diameter were then substituted in the following equation:

$$
\text { Angle of Repose }(\theta)=\tan -1[2 \mathrm{~h} / \mathrm{d}]
$$

Where, $\mathrm{h}$ - Height of the pile and $\mathrm{d}$ - Diameter of the pile. ${ }^{4,5}$

In Bulk Density and Tapped Density the weighed quantity (20 gm) of SR is carefully put into a measuring cylinder without any losses. The initial volume was noted and the sample was then tapped until no further reduction in volume was noted. The initial volume gave the bulk density value and after tapping the volume gives the value of tapped density.

Carr's index has been used as an indirect method of quantifying powder flowability from bulk density; this method was developed by Carr. The percentage compressibility of a powder is a direct measure of the potential powder arch or bridge strength and stability and is calculated according to the following equation.

$$
\text { Carr's index (\% compressibility) }=100 \times(1-\mathrm{Db} / \mathrm{Dt})
$$

Where $\mathrm{Db}=$ Bulk density, $\mathrm{Dt}=$ Tapped density.

Hausner ratio has also been used as an indirect method of quantifying powder flow ability from bulk density.

$$
\text { Hausner ratio }=D t / D b
$$

Where $\mathrm{Db}=$ Bulk density and $\mathrm{Dt}=$ Tapped density. All the experiments were repeated in triplicate. ${ }^{6,7}$

Physico-chemical Evaluation: The Physicochemical evaluation of prepared Safoof razyanaj (SR) was done by testing loss of weight on drying at $105^{\circ} \mathrm{C}$, total ash, acid insoluble ash, water soluble ash, $\mathrm{pH}$ of $1 \%$ and $\mathrm{pH}$ of $10 \%$ solution and extractive values.

Determination of $\mathbf{p H}: 1 \%$ and $10 \%$ solution of Safoof razyanaj was prepared in distilled water $(\mathrm{w} / \mathrm{v})$ and $\mathrm{pH}$ was determined by using digital pH meter. ${ }^{8}$

Loss on drying at $105^{\circ} \mathrm{C}$ : An accurately weighed $3 \mathrm{~g}$ of Safoof razyanaj was taken in apetri dish. The crude drug was heated at $105^{\circ} \mathrm{C}$ in an oven till a constant weight and percentage moisture content of the sample was calculated concerning the weighed Safoof razyanaj sample. ${ }^{9}$

Ash Values: Determination of total ash, acid insoluble ash and watersoluble ash is done as per protocol for testing of ASU drug. ${ }^{3}$

Extractive Values: In water soluble extractive value, five grams of Safoof razyanaj was macerated with $100 \mathrm{ml}$ of water in closed conical flask for
$24 \mathrm{hr}$, shaken frequently for the first $6 \mathrm{~h}$ and allowed to stand for $18 \mathrm{hr}$. This was filtered through filter paper. Twenty-five milliliters of the filtrate was evaporated to dryness in the petri dish, dried at $105^{\circ} \mathrm{C}$ and weighed. Percentage of water-soluble extractive concerning air-dried material was calculated.

In alcohol soluble extractive value, five grams of Safoof razyanaj was macerated with $100 \mathrm{ml}$ of $70 \%$ ethanol in a closed conical flask for $24 \mathrm{~h}$, shaken frequently during the first $6 \mathrm{hr}$ and allowed to stand for $18 \mathrm{~h}$. This was filtered rapidly taking precaution against loss of ethanol. Twenty-five milliliters of the filtrate was evaporated to dryness in a petri-dish, dried at $105^{\circ} \mathrm{C}$ and weighed. Percentage of alcohol-soluble extractive was calculated concerning the air-dried drug. ${ }^{9}$

Successive and Non-Successive Extractive Value: In successive extractive value, the coarse powder of Safoof razyanaj was extracted successively using soxhlet apparatus with different solvent, in increasing order of polarity, petroleum ether $\rightarrow$ benzene $\rightarrow$ chloroform-ethanol. $10 \mathrm{~g}$ powdered drug was taken and subjected to successive extraction with each solvent for $6 \mathrm{~h}$. After that, the extracts were filtered first by using filter paper (Whatman no. 1) and dried on a water bath. The extractive values were determined concerning the weight of the drug taken $(\mathrm{w} / \mathrm{w})$. The procedure was repeated 3 times to calculate mean extractive values.

In non-successive extractive value, the coarse powder of Safoof razyanaj was extracted separately in different solvent (water, ethyl alcohol and petroleum ether) using Soxhlet apparatus. $10 \mathrm{~g}$ powdered drug was taken and subjected to separate extraction with each solvent. The extracts were filtered first by using filter paper (Whatman no. 1) and evaporate on the water bath. Extractive values were determined concerning a drug is taken $(\mathrm{w} / \mathrm{w}) .^{10}$

Qualitative Estimation: Qualitative estimation for organic constituent's viz. alkaloid, glycosides, tannins, flavanoids, carbohydrates, saponins, phenols, proteins, resin, starch and steroids were done. ${ }^{8}$

HPTLC fingerprinting analysis: Qualitative densitometric HPTLC analysis was carried out at PES (People's Education Society) College of Pharmacy, Bengaluru to develop the characteristic fingerprint of Safoof razyanaj (SR). Extraction of Safoof razyanaj (SR) was done in methanol used for TLC application. Analysis was performed on $10 \times 10 \mathrm{~cm}$ silica gel $60 \mathrm{~F}_{254}$ plates. Sample solution was applied using Linomat 5 (Camag Switzerland) automated spray-on band applicator equipped with a $100 \mu$ l Hamilton syringe and operated with the settings as follows: Band length $8 \mathrm{~mm}$, distance from the plate edge $12.5 \mathrm{~mm}$ and distance from the bottom of the plate $10 \mathrm{~mm}$. Development of the plate was carried out allowing $20 \mathrm{~min}$ for saturation of the twin trough chamber (Camag Switzerland) at room temperature. Solvent system used was toluene: ethyl acetate: formic acid (5:4:1) for mobile phase and migration was $8 \mathrm{~cm}$. After development the plate was evaluated under UV $254 \mathrm{~nm}$ and $366 \mathrm{~nm}$ and evaluated under visible light using CAMAG TLC Visualiser and scanned using CAMAG TLC SCANNER-3. ${ }^{11}$

\section{RESULTS}

The powder characterization, Physicochemical Evaluation, Water and alcohol soluble extractive values, Successive and Non-Successive extraction, Phytochemical Screening and HPTLC data generated of Safoof razyanaj (SR) is depicted in (Table 2-8) respectively.

Table 2: Powder characterization of Safoof razyanaj (SR).

\begin{tabular}{cccccc}
\hline Parameters & $\begin{array}{c}\text { Bulk } \\
\text { density } \\
(\mathrm{gm} / \mathrm{ml})\end{array}$ & $\begin{array}{c}\text { Tapped } \\
\text { density } \\
(\mathrm{gm} / \mathrm{ml})\end{array}$ & $\begin{array}{c}\text { Car's } \\
\text { index }\end{array}$ & $\begin{array}{c}\text { Hausner's } \\
\text { Ratio }\end{array}$ & $\begin{array}{c}\text { Angle of } \\
\text { Repose }\end{array}$ \\
\hline Mean \pm SEM & $0.46 \pm$ & $0.56 \pm 0.00$ & $19.24 \pm$ & $1.23 \pm$ & $35.62 \pm$ \\
& 0.01 & & 0.59 & 0.00 & 0.45 \\
\hline
\end{tabular}


Table 3: pH and Loss on drying of Safoof razyanaj (SR).

\begin{tabular}{cccc}
\hline Parameters & $\begin{array}{c}\mathrm{pH} 1 \% \\
\text { solution }\end{array}$ & $\begin{array}{c}\mathrm{pH} 10 \% \\
\text { solution }\end{array}$ & $\begin{array}{c}\text { Loss on drying } \\
(\% \mathrm{w} / \mathrm{w})\end{array}$ \\
\hline Mean \pm SEM & $4.78 \pm 0.03$ & $5.08 \pm 0.02$ & $4.62 \pm 0.01$ \\
\hline
\end{tabular}

Table 4: Ash values of Safoof razyanaj (SR).

\begin{tabular}{cccc}
\hline Parameters & $\begin{array}{c}\text { Total ash } \\
(\% \mathrm{w} / \mathrm{w})\end{array}$ & $\begin{array}{c}\text { Acid insoluble } \\
\text { ash }(\% \mathrm{w} / \mathrm{w})\end{array}$ & $\begin{array}{c}\text { Water soluble ash } \\
(\% \mathrm{w} / \mathrm{w})\end{array}$ \\
\hline Mean \pm SEM & $4.95 \pm 0.05$ & $1.83 \pm 0.03$ & $2.1 \pm 0.03$ \\
\hline
\end{tabular}

Table 5: Successive Extraction and Non-Successive Extraction of Safoof razyanaj (SR).

\begin{tabular}{cccccccc}
\hline \multicolumn{3}{c}{ Successive extractive value $(\% w / w)$} & \multicolumn{5}{c}{ Non-Successive extractive value $(\% w / w)$} \\
\hline Parameters & Petroleum ether & Benzene & Ethanol & Petroleum ether & Benzene & Ethanol & Water \\
Mean \pm SEM & $11.24 \pm 0.14$ & $2.08 \pm 0.04$ & $6.73 \pm 0.10$ & $11.24 \pm 0.14$ & $15.44 \pm 0.24$ & $32.20 \pm 0.13$ & $34.28 \pm 0.18$ \\
\hline
\end{tabular}

Table 6: Phytochemical Screening of Safoof razyanaj (SR).

\begin{tabular}{ccc}
\hline S. No & Parameters & Results \\
\hline $\mathbf{1 .}$ & Alkaloids & + \\
$\mathbf{2}$. & Glycosides & + \\
$\mathbf{3 .}$ & Tannins & + \\
$\mathbf{4 .}$ & Flavanoids & + \\
$\mathbf{5 .}$ & Carbohydrates & + \\
$\mathbf{6 .}$ & Proteins & + \\
7. & Saponins & + \\
$\mathbf{8 .}$ & Terpenoids & + \\
9. & Phenols & + \\
\hline
\end{tabular}

Table 7: $R_{f}$ value, No. of Peaks, peak area and height of Safoof razyanaj (SR) at $254 \mathbf{n m}$.

\begin{tabular}{|c|c|c|c|c|c|c|c|c|c|}
\hline & Start Rf & Start Height & Max Rf & Max Height & Max \% & End $R_{f}$ & End Height & Area & Area \% \\
\hline 1 & 0.15 & 1.7 & 0.20 & 160.0 & 73.99 & 0.25 & 5.7 & 4332.0 & 72.71 \\
\hline 2 & 0.26 & 8.1 & 0.30 & 17.1 & 7.91 & 0.33 & 12.7 & 656.7 & 11.02 \\
\hline 4 & 0.61 & 6.9 & 0.63 & 12.7 & 5.87 & 0.66 & 3.4 & 294.3 & 4.94 \\
\hline 5 & 0.67 & 2.5 & 0.69 & 12.4 & 5.72 & 0.71 & 1.6 & 194.3 & 3.26 \\
\hline
\end{tabular}

Table 8: $R_{f}$ value, No. of Peaks, peak area and height of Safoof razyanaj (SR) at $366 \mathrm{~nm}$.

\begin{tabular}{|c|c|c|c|c|c|c|c|c|c|}
\hline Peak & Start $R_{f}$ & Start Height & $\operatorname{Max} R_{f}$ & Max Height & Max \% & End $R_{f}$ & End Height & Area & Area \% \\
\hline 1 & 0.16 & 0.0 & 0.19 & 12.2 & 11.87 & 0.21 & 6.5 & 265.6 & 9.19 \\
\hline 2 & 0.23 & 5.8 & 0.25 & 23.2 & 22.57 & 0.27 & 14.5 & 449.4 & 15.54 \\
\hline 3 & 0.28 & 14.6 & 0.30 & 26.5 & 25.82 & 0.36 & 10.7 & 1056.3 & 36.53 \\
\hline 4 & 0.52 & 5.5 & 0.55 & 28.3 & 27.49 & 0.58 & 7.7 & 687.9 & 23.79 \\
\hline 5 & 0.78 & 4.6 & 0.82 & 12.6 & 12.25 & 0.86 & 0.6 & 432.2 & 14.95 \\
\hline
\end{tabular}

\section{DISCUSSION}

Standardization is an important measure for knowing the quality and purity of the formulation and is necessary for the identity of the materials. Finished product of Safoof razyanaj (SR) is light brown in color, ${ }^{12}$ sweetest in taste, aromatic and without any clumping and aggregation. Sugar was taken equal to one part of drug in the formulation according to taste after trial and error, each one drug constitute $33.33 \%$ including sugar in the formulation. The mean values of bulk density, tapped density, angle of repose, Hausner's ratio and compressibility index were found to be $0.46 \pm 0.01,0.56 \pm 0.00,35.62^{\circ} \pm 0.45,1.23 \pm 0.00$ and $19.24 \pm 0.59$ respectively. (Table 2) Hausner's ratio and compressibility index are the simple and popular method to determine the flow characteristics of powder. The flow characteristics of powder depend on the size, shape, size distribution of particles and moisture content. Increase in the moisture content of a powder results in decreasing the ability to flow smoothly due to the increased thickness of adsorbed liquid layer, that enhance the strength of liquid bridges formed between particles. ${ }^{13}$ The Safoof razyanaj (SR) have Hausner's ratio of 1.26 to 1.34 , it indicates good flowability. As Hausner's ratio of less than 1.25 indicates good flow, whereas greater than 1.5 indicates poor flow characteristic. ${ }^{14}$ Table 2

$\mathrm{pH}$ value: $\mathrm{pH}$ of Safoof razyanaj (SR) in $1 \%$ solution was $4.78 \pm 0.03$ while the $\mathrm{pH}$ of $10 \%$ solution was $5.08 \pm 0.02$ (Table 3). It is towards slightly acidic in nature. Abba et al. in their study correlate the $\mathrm{pH}$ with microbial contamination as they suggest that a neutral or alkaline $\mathrm{pH}$ favours high microbial contamination levels of the herbal preparations. As the $\mathrm{pH}$ of the test formulation was 5.31 or less and microbial count was also within normal limit as per WHO guidelines, it is in accordance 
to the observation of Abba et al. ${ }^{15}$ (Table 3) LOD: The mean percentage of loss of weight on drying of Safoof razyanaj was $4.62 \pm 0.10$. It is mentioned that the water content in plant drugs can vary between $8 \%$ and $14 \%$. The presence of excessive amount of moisture in plant drugs causes hydrolysis of constituents, growth of bacteria and fungi and biochemical reactions. The pharmacopoeial monographs compulsorily limit the water content, especially in drugs that have hygroscopic nature, or in which the excessive amounts of water causes deterioration of products. ${ }^{14,16}$ (Table 3) As finished Safoof razyanaj (SR) contains very less amount of moisture it can be expected that it will be safe for long time. Ash Values: The total ash, acid insoluble ash and water soluble ash was found to be $4.95 \pm 0.05,1.83 \pm 0.03$ and $2.1 \pm 0.03$ respectively. (Table 4 ) The ash value is an important parameter because a high ash value is indicative of contamination, substitution, adulteration or carelessness in preparing the drug or drug combinations. These values were found to be reasonably low indicating low contamination. Water-soluble ash is the part of the total ash content, which is soluble in water. It is a good indicator of either previous extraction of water-soluble salts in the drug or incorrect preparation. Thus, it is the difference in weight between the total ash and the residue obtained after treatment of total ash with water. ${ }^{17}$

Extractive values: The water and alcohol soluble extractive values of Safoof razyanaj (SR) were found to be $38.25 \pm 0.10$ and $14.88 \pm 0.11$ respectively. The successive extractive values in petroleum ether, benzene and ethyl alcohol were found to be $11.24 \pm 0.14,2.08 \pm 0.04$ and $6.73 \pm 0.10$ respectively. While as the non-successive extractive values in petroleum ether, benzene, ethyl alcohol and water were $11.24 \pm 0.14,15.44 \pm 0.24,32.20 \pm 0.13$ and $34.28 \pm 0.18$ respectively. (Table 5) Extractive value of a drug in definite solvent is an index for checking the purity of a drug. Amount of the extract of a drug in a particular solvent is often an appropriate measuring tool for certain constituent in the drug. ${ }^{18}$

Qualitative estimation: Organic constituents viz. alkaloid, glycosides, tannins, flavanoids, carbohydrates, saponins, phenols, proteins, flavanoids, terpenoids were qualitatively estimated. (Table 6) HPTLC: HPTLC plates of Safoof razyanaj (SR) in mobile phase.

Toluene: Ethyl acetate: Formic acid (5:4:1) was examined. $R_{f}$ value, numbers of peaks, peak area and peak height were also analysed under $254 \mathrm{~nm}, 366 \mathrm{~nm}$. (Figure 2-4) Area percentage of peak no. 1 of Safoof razyanaj (SR) analysed under $254 \mathrm{~nm}$ in toluene: ethyl acetate: formic acid (5:4:1) was highest (72.71\%). (Table 7) Area percentage of peak no. 3 of Safoof razyanaj (SR) analysed under $366 \mathrm{~nm}$ in toluene: ethyl acetate:

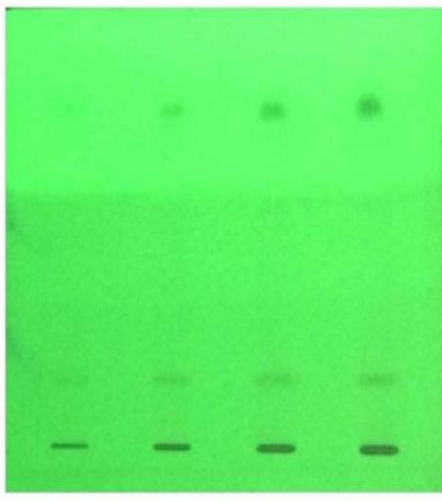

At $254 \mathrm{~nm}$

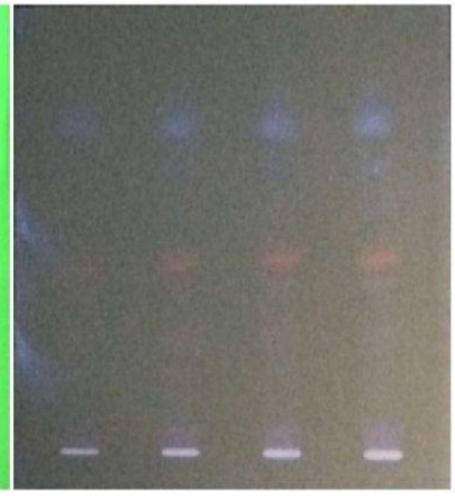

At $366 \mathrm{~nm}$
Figure 2: HPTLC Fingerprinting (TLC Profile) of methanolic extract of Safoof razyanaj (SR) in toluene: ethyl acetate: formic acid at $254 \mathrm{~nm}$ and $366 \mathrm{~nm}$.

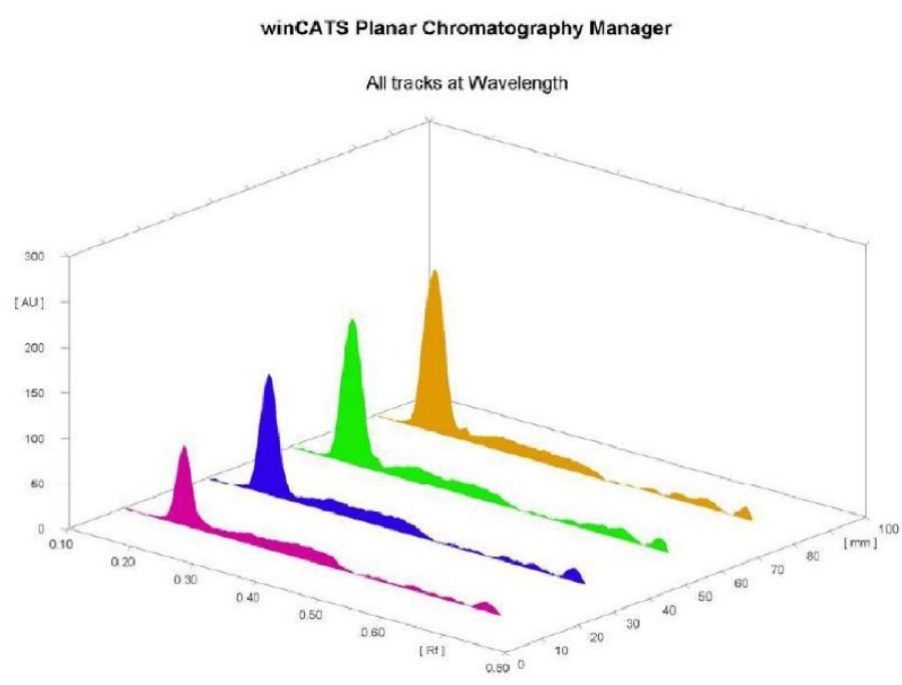

Figure 3: HPTLC 3-D Densitometric Scan of methanolic extract of Safoof razyanaj (SR) in toluene: ethyl acetate: formic acid at $254 \mathrm{~nm}$.

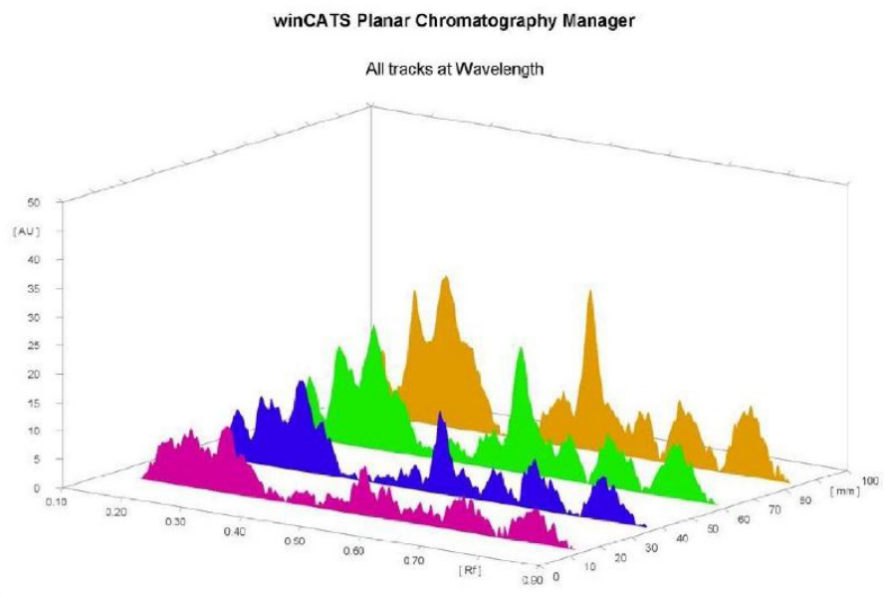

Figure 4: HPTLC 3-D Densitometric Scan of methanolic extract of Safoof razyanaj (SR) in toluene: ethyl acetate: formic acid at $366 \mathrm{~nm}$.

formic acid (5:4:1) was highest (36.53\%). (Table 8) Further studies can also be done by the help of standards and quantitative estimation and identification of the ingredients. Present HPTLC fingerprinting data can help in authentication and identification of Safoof razyanaj (SR) in the performed solvent system and extract.

\section{CONCLUSION}

The most important lacunae to the alternative system of medicine for its globalization is to ensure uniformity and quality drugs. At present this powder dosage form Safoof razyanaj (SR) doesn't have any Pharmacopoeial standards since yet. Various methods and parameters for the assessment of powder dosage form are mentioned in different guidelines and it is necessary to follow these guidelines so that these data could be used to set the standards for the formulation and could be taken as standard for quality control purpose to achieve maximum efficacy and safety of medicine. So, in this present study, the test drug Safoof razyanaj (SR) was evaluated to set its standards which were found in accordance to WHO standards. This work may be used as standard monograph for identification and evaluation of the other such formulations. 


\section{ACKNOWLEDGEMENT}

The authors would like to express their thanks to Director, National Institute of Unani Medicine (NIUM) Bangalore, for providing all the essential assistance and motivation to work and Dr. Nagraaj, HOD, Department of Pharmaceutical Analysis, PES College of Pharmacy, Bangalore for HPTLC work.

\section{CONFLICT OF INTEREST}

There are no conflicts of interest.

\section{ABBREVIATIONS}

WHO: World Health Organisation; USM: Unani System of Medicine; SR: Safoof razyanaj, ASU: Ayurvedic Siddha Unani; HPTLC: High Performance Thin Layer Chromatography; SEM: Standard Error of Mean; LOD: Loss on Drying; UPI: Unani Pharmacopeia of India; TLC: Thin Layer Chromatography; SOP: Standard Operational Procedure. Q.S: Quantity sufficient.

\section{REFERENCES}

1. Afaq SH, Tajuddin, Shamshad A, Abdullah, Azizur R. Standardization of Unani Ointments Marham Kafoor. Hippocratic J Unani Med. 2012;12-25.

2. National Fromulary of Unani Medicine, Government of India, Ministry of Health and Family Welfare (Department of AYUSH), New Delhi, Part VI. 2016;106.

3. Protocol for testing Ayurvedic, siddha and Unani medicines, Ghaziabad, Ministry of Health and Family Welfare, Dept of Ayush Govt. of India. YNM: 2008;40:49-50.

4. Rather GJ, Hamiduddin, Ikram M, Fatima S, Naquibuddin MD. Physicochemical Standardization of Polyherbal Powder Formulation: Safoof-e-Makhana. Pharmacog J. 2018;10(5):900.

5. Patel NJ, Lakshmi CS, Patel HP, Akul S. Formulation and evaluation of Oral dispersible tablets of cinnarizine using direct compression technique. IJPSR $2011 ; 2(4): 961-7$.

6. Lachman L, Liberman HA, Kanig JL. The Theory and Practice of Industrial Pharmacy. Mumbai: Varghese Publishing House $3^{\text {rd }}$ ed. 2005;67.

7. World Health Organization, Bulk Density and Tapped Density of Powders. Document QAS/11.450 FINAL Geneva 2012; 1-6. Available at URL: http:// www. who.int/medicines/ publications/ pharmacopoeia/ Bulk-tapped- density.

8. Physicochemical standardization of Unani formulations. Part IV. New Delhi; CCRUM, Ministry of $\mathrm{H}$ and FW, Govt. of India. 2006;142-5.

9. The Unani Pharmacopoeia of India. Part II Vol. II, First edition. New Delhi: Government of India, Ministry of Health and Family Welfare, Dept of AYUSH. 2010;158:159-209.

10. Ali W, Shaikh H, Ansari A, Khanam S. Standardization of Unani Antidiabetic Tablet -Qurse Tabasheer. Pharmacogn Res. 2016;8(2):147-52.

11. Chatterjee K, Ali KM, De D, Panda DK, Ghosh D. Antidiabetic and antioxidative activity of ethyl acetate fraction of hydromethanolic extract of seed of Eugenia jambolana Linn through in-vivo and in-vitro study and its chromatographic purification. FRA. 2012;2(1):21-30.

12. Pantone colour chart: https://www. pantone.com/color-finder?q=114.

13. Emery E. Flow Properties of Selected Pharmaceutical Powders. Saskatchewan, University of Saskatchewan. 2008;9-10.

14. Aulton EM. Aultons Pharmaceutics. London: Churchill Livingstone. 2009;356.

15. Abba D, Inabo HI, Yakubu SE, Olonitola OS. Contamination of Herbal Medicinal Products Marketed in Kaduna Metropolis with Selected Pathogenic Bacteria. Afr J Tradit Complement Altern Med. 2008;6(1):70-7.

16. Júnior JOCS, Costa RMR, Teixeira FM, Barbosa WLR, Shoyama Y. Processing and Quality Control of Herbal Drugs and Derivatives. In: Quality Control of Herbal Medicines and Related Areas. In Tech, Brazil. 2011;211:195-222. [Cited on 02-11-18]. Available at URL: http://cdn.intechopen.com/pdfs-wm/23473.pdf.

17. Chandel HS, Pathak AK, Tailang M. Standardization of some herbal antidiabetic drugs in polyherbal formulation. Pharmacogn Res. 2011;3(1):49.

18. Jahan N, Afaque SH, Khan G, Ansari AA. Physicochemical studies of the Gum acacia. Nat Prod Radiance. 2008:7:335-7.

Article History: Submission Date : 14-06-2019; Revised Date : 21-08-2019; Acceptance Date : 06-09-2019.

Cite this article: Ikram M, Hamiduddin, Rather GJ, Zaigham M. Quality Standard of Safoof razyanaj: A Unani Polyherbal Powder Formulation. J Young Pharm. 2019;11(4):361-5. 